\title{
Relations between transit time, fermentation products, and hydrogen consuming flora in healthy humans
}

\author{
L El Oufir, B Flourié, S Bruley des Varannes, J L Barry, D Cloarec, F Bornet, \\ J P Galmiche
}

\begin{abstract}
Background/Aims-To investigate whether transit time could influence $\mathrm{H}_{2}$ consuming flora and certain indices of colonic bacterial fermentation.

Methods-Eight healthy volunteers (four methane excretors and four non-methane excretors) were studied for three, three week periods during which they received a controlled diet alone (control period), and then the same diet with cisapride or loperamide. At the end of each period, mean transit time (MTT) was estimated, an $\mathrm{H}_{2}$ lactulose breath test was performed, and stools were analysed.
\end{abstract}

Results-In the control period, transit time was inversely related to faecal weight, sulphate reducing bacteria counts, concentrations of total short chain fatty acids (SCFAs), propionic and butyric acids, and $\mathrm{H}_{2}$ excreted in breath after lactulose ingestion. Conversely, transit time was positively related to faecal pH and tended to be related to methanogen counts. Methanogenic bacteria counts were inversely related to those of sulphate reducing bacteria and methane excretors had slower MTT and lower sulphate reducing bacteria counts than non-methane excretors. Compared with the control period, MTT was significantly shortened $(p<0.05)$ by cisapride and prolonged $(p<0.05)$ by loperamide $(73$ (11) hours, 47 (5) hours and 147 (12) hours for control, cisapride, and loperamide, respectively, mean (SD)). Cisapride reduced transit time was associated with (a) a significant rise in faecal weight, sulphate reducing bacteria, concentrations of total SCFAs, and propionic and butyric acids and breath $\mathrm{H}_{2}$ as well as (b) a significant fall in faecal $\mathrm{pH}$ and breath $\mathrm{CH}_{4}$ excretion, and (c) a non-significant decrease in the counts of methanogenic bacteria. Reverse relations were roughly the same during the loperamide period including a significant rise in the counts of methanogenic bacteria and a significant fall in those of sulphate reducing bacteria.

Conclusions-Transit time differences between healthy volunteers are associated with differences in $\mathrm{H}_{2}$ consuming flora and certain indices of colonic fermentation. Considering the effects of some fermentation products on intestinal morphology and function, these variations may be relevant to the pathogenesis of colorectal diseases.

(Gut 1996; 38: 870-877)

Keywords: transit time, $\mathrm{H}_{2}$ consuming flora, hydrogen, methane, short chain fatty acids.

Through fermentation the colonic flora generates short chain fatty acids (SCFAs), carbon dioxide, and hydrogen $\left(\mathrm{H}_{2}\right) . \mathrm{H}_{2}$ released in the colon may be consumed by methanogenic bacteria (MB) producing methane and by sulphate reducing bacteria (SRB) and acetogenic bacteria. ${ }^{1}$

There are considerable inter-individual variations in the composition of faecal flora. ${ }^{23}$ As different species make different contributions to the production of individual SCFAs, inter-subject variations in the faecal proportions of acetate, propionate, and butyrate also occur, ${ }^{45}$ and in vitro faecal fermentation patterns of a given substrate differ between subjects. ${ }^{67}$ There are also large individual variations in the activities of flora producing or consuming $\mathrm{H}_{2}$. The amounts of $\mathrm{H}_{2}$ excreted in breath in response to identical loads of fermentable carbohydrates and the quantities of methane exhaled, as well as faecal $\mathrm{MB}$ concentrations, differ considerably among subjects. ${ }^{18}$

The factors affecting the composition and activities of colonic flora, and which could account for inter-individual variations, are largely unknown. The factors likely to be important include age, diet, colonic $\mathrm{pH}$ and microbial interactions, colonic supply, and availability of nutrients, bile acids and sulphate, and microbial adaptation to metabolise these substrates. ${ }^{1269-11}$ Transit time through the gut may be expected to affect colonic flora because it influences both the amount of substrates flowing to the large bowel ${ }^{12}{ }^{13}$ and the efficiency of colonic fermentation. ${ }^{14}$ Consequently, the availability of substrate and energy for the colonic flora, as well as the $\mathrm{pH}$ of luminal contents, are changed. In addition, some data suggest that transit itself could affect the composition and activities of colonic flora. Indeed, the faecal bacterial mass is related to transit time in human subjects on identical dietary intakes. ${ }^{1516}$ Likewise, in in vitro continuous culture in which bacteria are grown with a constant substrate supply, bacterial cell growth depends on turnover time, ${ }^{17-19}$ and changes in turnover time also affect the pattern of fermentation products. ${ }^{1819}$ Moreover, fast 
transit time through the large bowel could impede SCFAs absorption, leading to sustained acidification of the contents, and modify colonic stirring, which has been shown to control $\mathrm{H}_{2}$ consumption. ${ }^{20}$ Conversely, slow transit time seems to be physiologically associated with methane production by slow growing $\mathrm{MB}$, although findings are not consistent. ${ }^{21-24}$

In normal subjects, transit time through the small intestine and whole gut varies greatly between people. ${ }^{25-28}$ For example, a threefold range in mean transit time (MTT) has been found in men consuming identical diets. ${ }^{1629}$ Individual variations in transit time could thus influence the composition and activities of colonic flora, which could account in part for its inter-subject variations. To test this hypothesis, we studied the relations between transit time, $\mathrm{H}_{2}$ consuming bacteria, and certain indices of bacterial fermentation in healthy volunteers given a constant diet. As transit may be the result rather than the cause of colonic events, we further changed this variable by pharmacological means and measured the changes in $\mathrm{H}_{2}$ consuming flora and fermentation products.

\section{Methods}

Subjects

The study was performed in eight healthy adults (three males and five females, 26-35 years). None had received antibiotics, laxatives or enemas during the three months preceding the study. As approximately $50 \%$ of the French population are methane excretors, ${ }^{30}$ we enrolled four subjects who were identified as methane excretors (methane + ) on the basis of breath methane concentrations that were at least one part per million (ppm) above room atmosphere and four who were non-methane excretors (methane-). The protocol was approved by the local ethics committee, and all investigations were undertaken after written informed consent was given by the subjects.

Study design

We applied the protocol designed by Stephen et $a l,{ }^{16}$ and divided study time into three, three week periods. The first period served as a control, whereas subjects received either cisapride or loperamide in random order during the two subsequent three week periods. During each period, subjects consumed the same controlled diet and collected their stools. Radio-opaque pellets were used for MTT measurement.

According to the sex, subjects could feed in rotation on five one day isocaloric menus of similar composition. For women, daily energy intake was $8.36 \mathrm{MJ}$ (consisting in $79 \mathrm{~g}$ protein, $91 \mathrm{~g}$ fat, and $223 \mathrm{~g}$ carbohydrate), and for men, it was $10.45 \mathrm{MJ}$ (consisting in $81 \mathrm{~g}$ protein, $92 \mathrm{~g}$ fat, and $311 \mathrm{~g}$ carbohydrate). Additional carbohydrates in men came from foods containing simple sugars. Both diets were designed to contain twice the usual daily French intake of dietary fibre (that is, $15 \mathrm{~g} \times 2$ ) to provide sufficiently fast transit time in the control period such that it could be then changed during the loperamide treatment without distress to the participants.

Throughout the study, subjects took 30 radio-opaque pellets per day ( 10 per meal) as non-absorbable markers. Two marker shapes were used: small squares and circles. The type of marker was changed at the end of each three week period, so that total marker recovery during each period could be estimated. Subjects collected stools throughout the study and for one week after to assess the total recovery of ingested markers. Each stool was collected separately in a plastic bag suspended over the toilet and immediately frozen. The number of markers present in each stool was counted after radiographing. Transit measurements were done using the continuous marker technique described by Cummings et al, ${ }^{31}$ which permits continuous day by day MTT measurement. Drug therapy was titrated to approximately double or halve the spontaneous transit time of subjects. Cisapride tablets (10 mg tablets) (Prepulsid, Janssen, Boulogne, France) were used to speed up transit. Initially two tablets were given (one with breakfast and the other with dinner), and the dose was increased by one tablet per day up to 60 $\mathrm{mg} /$ day if the desired effect was not achieved. Transit was slowed down using loperamide (2 mg tablets) (Imodium, Janssen, Boulogne, France). Initially, two tablets were used, and the dose was increased up to $10 \mathrm{mg} /$ day if sufficient slowing in transit time did not occur. All adjustments were made during the first week of each period. The final daily doses of drugs were $40 \mathrm{mg}(\mathrm{n}=2)$ and $60 \mathrm{mg}(\mathrm{n}=6)$ for cisapride, and $6 \mathrm{mg}(\mathrm{n}=1), 8 \mathrm{mg}(\mathrm{n}=4)$, and $10 \mathrm{mg}(\mathrm{n}=3)$ for loperamide. Stools collected from days 14 to 21 of each period were weighed, and the percentage of dry matter in stool aliquot was determined after freeze drying. MTT was calculated as the average value for the last seven days of control, cisapride, and loperamide periods.

\section{Lactulose $\mathrm{H}_{2}$ breath tests}

After a standardised low residue evening meal and a 12 hour fast, subjects ingested $10 \mathrm{~g}$ lactulose (Duphalac, Duphar, Villeurbanne, France) alone or with the drug (cisapride or loperamide) on the last day of each three week period. After a thorough mouth rinse with a $1 \%$ chlorhexidine solution (Givalex, Norgan Laboratoires, Paris, France), three basal samples of end expiratory air were collected before lactulose ingestion. Further samples were taken every 10 minutes during the first two hours and every 15 minutes thereafter for eight hours. During the tests, smoking and eating were not permitted, and the subjects were non-ambulant. $\mathrm{H}_{2}$ and methane concentrations in breath samples were determined simultaneously using a Quintron model DP instrument (Quintron Microlyser, Milwaukee, WI, USA) and expressed as parts per million ( $1 \mathrm{ppm}=$ approximately $0.05 \mu \mathrm{mol} / \mathrm{l})$. 


\section{Analytical methods}

Freshly voided stool obtained from days 18 to 21 of each period were immediately refrigerated at $4^{\circ} \mathrm{C}$ under anaerobic conditions (Anaerocults A; Merck, Darmstadt, Germany) for no longer than two hours before processing. Stools were homogenised and diluted in anaerobic solution (containing (g/l): $\mathrm{NaCl}$, 5; glucose, 2; cysteine. $\mathrm{HCl}, 0.3$ and $5 \%$ minerals, $0.5 \%$ oligoelements, and $0.5 \%$ vitamins) to give a 10 -fold dilution (wet weight/volume). Faecal pH was measured using a pH meter (Micro pH 2000, Crison, Paris, France), and serial 10-fold dilutions were made.

Total anaerobes were measured in WilkinsChalgren agar (Difco Laboratories, Detroit MI, USA). For this purpose $1 \mathrm{ml}$ of each 10fold dilution was inoculated into $13 \mathrm{ml}$ Wilkins-Chalgren agar at $45^{\circ} \mathrm{C}$. Innoculated medium was then poured into $8 \times 400 \mathrm{~mm}$ tubes (in duplicate), which were immediately cooled to ensure prompt solidification. ${ }^{32}$

Total SRB were counted similarly in the medium of Pfenning et al. ${ }^{33}$ Lactate was used as a substrate for dissimilatory sulphate reduction as it serves as a substrate to the major SRB population of the human large intestine ${ }^{1}$ and that all species characterised to date utilise $\mathrm{H}_{2}$ as electron donor. ${ }^{34}$

Total $\mathrm{MB}$ were measured by most probable number estimation in Balch 1 broth. ${ }^{35}$ Triplicate 10-fold dilution series were prepared in the anaerobic chamber using the anaerobic solution described above $(9 \mathrm{ml}$ in 30 $\mathrm{ml}$ vials) and incubated for each dilution between $10^{-2}$ and $10^{-11}$. The gas phase of each vial was pressurised weekly at $202 \mathrm{kPa}$ using $\mathrm{H}_{2} / \mathrm{CO}_{2}$ (4:1). Headspace gas samples were removed after 15 days to measure methane concentrations by gas chromatography (N 200, Delsi Nermag Instrument, Argenteuil, France). Vials with methane concentrations above $200 \mathrm{ppm}$ were considered positive. ${ }^{36}$ Positive responses at each dilution level were counted, and the most probable numbers calculated.

For the last two subjects studied (one methane + and one methane-), acetogenic bacteria were measured by most probable number estimation in AC-11 broth as described by Greening and Leedle. ${ }^{37}$ Triplicate 10 -fold dilution series were prepared in the anaerobic chamber using the same anaerobic solution (9 $\mathrm{ml}$ in $30 \mathrm{ml}$ vials) and incubated for each dilution between $10^{-1}$ and $10^{-11}$. The gas phase of

TABLE I Mean transit time, stool weight, and counts of total anaerobes, methanogenic bacteria, and sulphate reducing bacteria in stools collected during the control period from eight healthy volunteers (four $\mathrm{CH}_{4}$ excretors $\left(\mathrm{CH}_{4}^{+}\right)$and four non- $\mathrm{CH}_{4}$ excretors $\left(\mathrm{CH}_{4}^{-}\right)$)

\begin{tabular}{llllllll}
\hline Subjects & Sex & $\begin{array}{l}\text { Mean } \\
\text { transit } \\
\text { time }(h)\end{array}$ & $\begin{array}{l}\text { Stool } \\
\text { weight } \\
\text { (g/day) }\end{array}$ & $\begin{array}{l}\text { Methane } \\
\text { excretor } \\
\text { status }\end{array}$ & $\begin{array}{l}\text { Total } \\
\text { anaerobes }\end{array}$ & $\begin{array}{l}\text { Methanogenic } \\
\text { bacteria }\end{array}$ & $\begin{array}{l}\text { Sulphate } \\
\text { reducing } \\
\text { bacteria }\end{array}$ \\
\hline 1 & $\mathrm{~F}$ & 122 & 107 & $\mathrm{CH}_{4}^{+}$ & $11 \cdot 3$ & $9 \cdot 8$ & $7 \cdot 3$ \\
2 & $\mathrm{~F}$ & 99 & 92 & $\mathrm{CH}_{4}^{+}$ & $10 \cdot 2$ & $9 \cdot 8$ & $7 \cdot 4$ \\
3 & $\mathrm{M}$ & 63 & 198 & $\mathrm{CH}_{4}^{+}$ & $10 \cdot 9$ & $8 \cdot 7$ & $7 \cdot 9$ \\
4 & $\mathrm{~F}$ & 98 & 100 & $\mathrm{CH}_{4}^{+}$ & $10 \cdot 8$ & $9 \cdot 8$ & $8 \cdot 1$ \\
5 & $\mathrm{~F}$ & 41 & 180 & $\mathrm{CH}_{4}^{-}$ & $11 \cdot 5$ & $<2$ & $9 \cdot 0$ \\
6 & $\mathrm{~F}$ & 44 & 141 & $\mathrm{CH}_{4}^{-}$ & $10 \cdot 5$ & $4 \cdot 1$ & $8 \cdot 4$ \\
7 & $\mathrm{M}$ & 41 & 233 & $\mathrm{CH}_{4}^{-}$ & $10 \cdot 6$ & $6 \cdot 7$ & $8 \cdot 4$ \\
8 & $\mathrm{M}$ & 74 & 150 & $\mathrm{CH}_{4}^{-}$ & $11 \cdot 0$ & $<2$ & $8 \cdot 4$ \\
Mean (SEM) & & $73(11)$ & $150(18)$ & $4\left(4^{-}\right)$ & $10 \cdot 9(0 \cdot 1)$ & $6 \cdot 1(1 \cdot 5)$ & $8 \cdot 1(0 \cdot 2)$ \\
\hline
\end{tabular}

^Results are expressed as $\log _{10}$ viable micro-organisms per $\mathrm{g}$ of wet weight. each vial was pressurised weekly at $202 \mathrm{kPa}$ using $\mathrm{H}_{2} / \mathrm{CO}_{2}(4: 1)$. For each dilution between $10^{-1}$ and $10^{-11}$, two control vials were prepared and pressurised weekly at $151.5 \mathrm{kPa}$ using $\mathrm{N}_{2}$. Samples were removed after 21 days to measure acetic acid concentrations by gas chromatography (DN 200, Delsi Nermag Instrument). Vials with acetic acid concentrations above the mean of the two control vials were considered positive. ${ }^{37}$

An aliquot of homogenised stools was mixed with a solution containing $1 \%(\mathrm{w} / \mathrm{v})$ mercuric chloride and $0.61 \%(\mathrm{v} / \mathrm{v})$ orthophosphoric acid in distilled water and then stored at $-20^{\circ} \mathrm{C}$. Thawed aliquots were centrifuged at $5000 \mathrm{~g}$ for 15 minutes. After addition of internal standard (4-methyl valeric acid), SCFA concentration was determined by gas chromatography (N 200, Delsi Nermag Instrument). ${ }^{38}$

\section{Calculations and statistical analysis}

Mouth to caecum transit time (MCTT) was defined as the period from lactulose intake until the period just before the initial increase above fasting levels of $10 \mathrm{ppm}$ or more $\mathrm{H}_{2}$ when this increase was sustained. Breath excretions of $\mathrm{H}_{2}$ and methane were estimated by integrating the area under the concentration curve (AUC) located between 0 and 600 minutes.

Stool data collected at the end of each period were expressed as daily mean (SEM). The quantitative results of bacteriological culture were expressed as the $\log _{10}$ of colony forming units per $\mathrm{g}$ wet weight faeces. One way analysis of variance and paired $t$ tests were used to compare means from the three periods. Because of the curvilinear nature of curves between transit and the parameters studied, $\log$ MTT was used to calculate correlations between MTT and each parameter by simple regression. Student's unpaired $t$ test was used to compare data between methane and nonmethane excretors.

\section{Results}

Mean transit time and stool weight

Some 99 (3)\% of markers ingested during the study were recovered in stools, thereby permitting accurate MTT estimates.

During the control period, with similar intake of dietary fibre, MTT ranged from 41 to 122 hours and faecal output from 92 to 233 g/day (Table I). Figure 1 shows the individual daily MTT values after marker equilibrium was reached during the control period. Although MTT variations occurred from day to day, on the whole each subject had a tendency to maintain a rather constant, either fast or slow, MTT. MTT was inversely related to stool weight and the percentage of faecal water $(r=0.79, \mathrm{p}<0.02, \mathrm{n}=8$ and $r=-0.76, \mathrm{p}<0.02$, $\mathrm{n}=8$ respectively).

Figure 2 shows MTT changes during cisapride and loperamide administration. Compared with the control period, MTT was significantly shortened by cisapride (47 (5) $v 73$ 
(11) hours, $\mathrm{p}<0.05)$ and significantly lengthened by loperamide (147 (12) $v 73$ (11) hours, $\mathrm{p}<0.001)$. Changes in MTT induced by cisapride and loperamide were associated with significant variations in daily stool outputs (Fig 2).

Over the three periods, MTT was inversely related to faecal weight $(r=-0.89, \mathrm{p}<0.001$, $\mathrm{n}=24$ ) and percentage of faecal water $(r=-0.82, \mathrm{p}<0.001, \mathrm{n}=24)$.

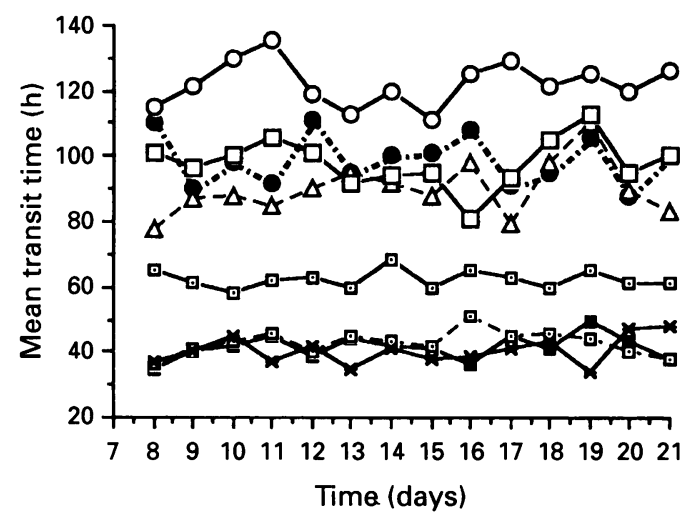

Figure 1: Individual daily mean transit time measured after marker equilibrium during the control period in eight healthy volunteers.
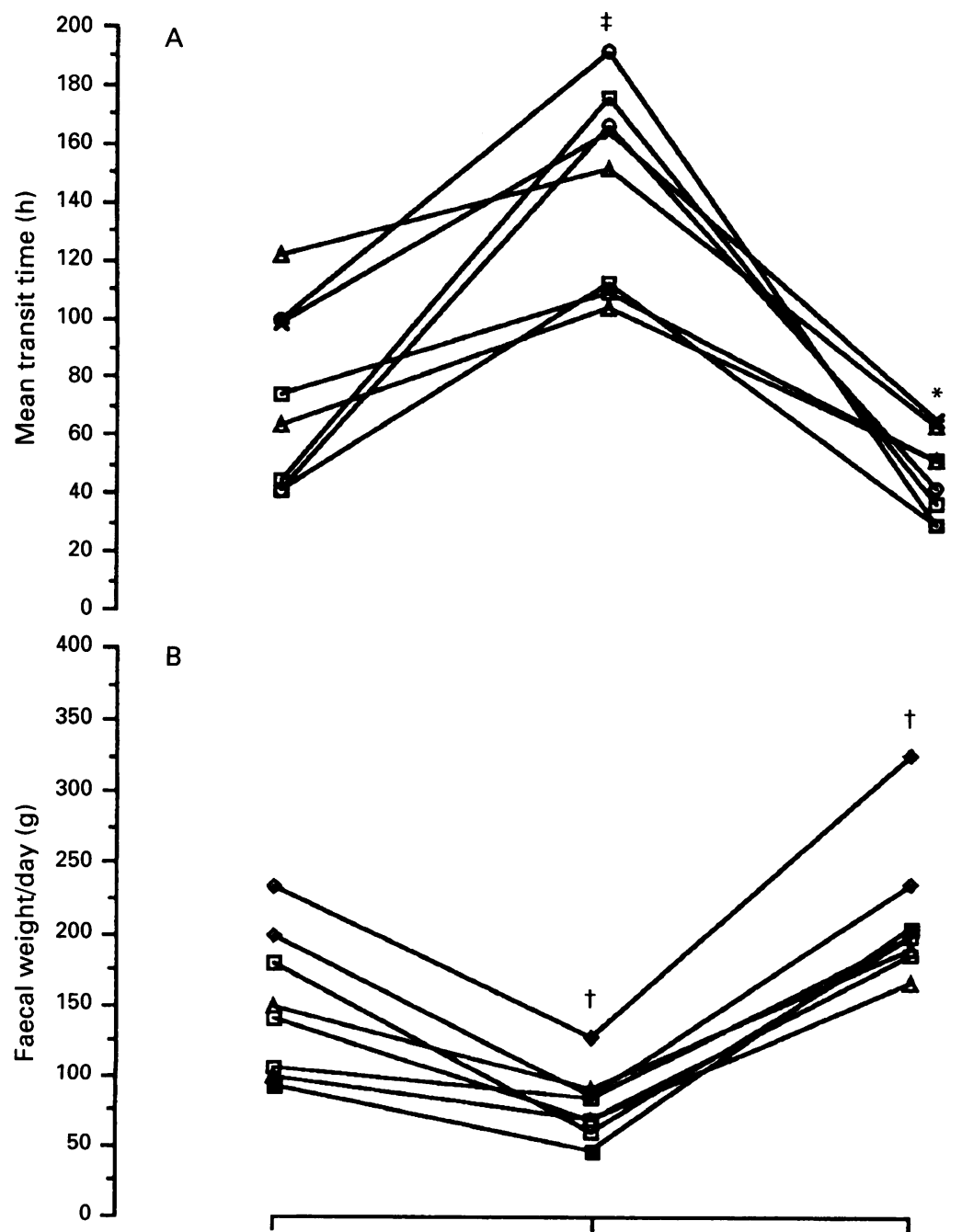

B

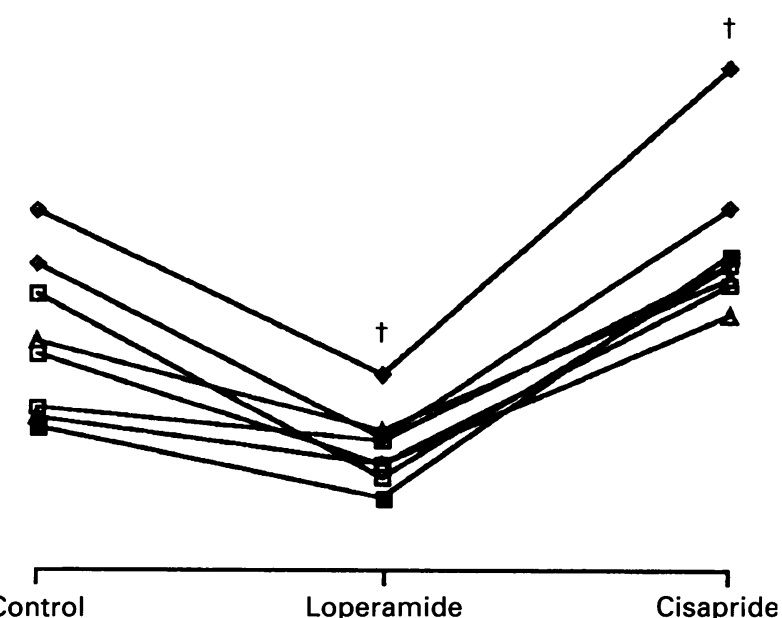

Figure 2: Mean transit time (A) and daily faecal weight $(B)$ during the last seven days of the control, loperamide, and cisapride periods. ${ }^{\star} p<0.05, \dagger p<0.005, \ddagger p<0.001 \mathrm{v}$ control period.
Mean transit time and faecal bacterial counts During the control period, total viable anaerobes ranged from 10.2 to $11.5 \log _{10} / \mathrm{g}$ wet weight (Table I). In methane,$+ \mathrm{MB}$ ranged from $8 \cdot 7$ to $9 \cdot 8 \log _{10} / g$ wet weight. SRB, which were detected in all subjects, ranged from $7 \cdot 3$ to $9 \cdot 0 \log _{10} / g$ wet weight. SRB counts differed significantly between methane + and methane - $\left(7.7(0.2) v 8.6(0.1) \log _{10} / \mathrm{g}\right.$ wet weight, $\mathrm{p}<0.05)$, and were negatively related to MB counts $(r=-0.82, \mathrm{p}<0.02, \mathrm{n}=8)$. MTT was significantly higher in methane+ than methane- (96 (12) v 50 (8) hours, $\mathrm{p}<0.05)$ and was negatively related to SRB counts $(r=-0.83, \mathrm{p}<0.02, \mathrm{n}=8)$.

Table II shows the changes in the counts of total viable anaerobes as well as MB and SRB induced by cisapride and loperamide administration. Total viable anaerobes were not significantly changed by drugs. Compared with the control period, the administration of loperamide induced a significant increase in MB counts $(p<0.05)$ and a significant decrease in SRB counts $(p<0.005)$. Conversely, with cisapride $M B$ tended to be lower $(p=0.07)$, whereas SRB were significantly higher $(p<0.05)$. In the two subjects in whom MB were below the detection level, neither MB nor SRB counts were changed by cisapride or loperamide administration. In the two subjects tested, acetogenic bacteria counts were unchanged during the three periods (Table II).

Over the three periods, MTT correlated with $\mathrm{MB}$ counts $(r=0.58, \mathrm{p}=0.01, \mathrm{n}=24)$ and was inversely related to SRB counts $(r=-0 \cdot 78$, $\mathrm{p}<0.001, \mathrm{n}=24$ ).

Mean transit time, MCTT, $\mathrm{H}_{2}$, and methane excretion in breath after lactulose ingestion During the control period, fasting $\mathrm{H}_{2}$ concentrations were $2.7(0.4)$ and $2.8(0.6) \mathrm{ppm}$ in methane + and methane- - Fasting methane concentrations were $17(4) \mathrm{ppm}$ and $1 \cdot 0(0 \cdot 1)$ ppm in methane + and methane - . MTT was closely related to MCTT $(r=0.97, \mathrm{p}<0.001$, $\mathrm{n}=8$ ) and was inversely related to AUC of $\mathrm{H}_{2}$ exhaled after lactulose ingestion $(r=-0.83$, $\mathrm{p}<0.02, \mathrm{n}=8$ ).

Compared with the control period, cisapride administration induced a significant decrease in MCTT (97 (6) $v 160$ (13) minutes, $\mathrm{p}<0.05)$ and a significant increase in $\mathrm{H}_{2}$ excretion in breath as assessed by the AUC of $\mathrm{H}_{2}$ $(p<0.05)$ (Fig 3, Table III). In methane+, fasting methane concentration and consequently the AUC of methane were significantly reduced during cisapride administration (10 (3) $v 17$ (4) $\mathrm{ppm}, \mathrm{p}<0.01$ and $1.9(0.2) v 3.4$ (0.3) $10^{3} \mathrm{ppm} / \mathrm{min}, \mathrm{p}<0.05$, Fig 3). MCTT and the AUC for $\mathrm{H}_{2}$ were not significantly affected during loperamide administration (200 (24) $v 160$ (13) minutes, $\mathrm{p}=0.20$ and $7 \cdot 7$ (0.9) v $9.4(1.5) 10^{3} \mathrm{ppm} / \mathrm{min}, \mathrm{p}=0.30$ ) (Fig 3, Table III). In methane + , fasting methane concentration and consequently the AUC of methane were significantly increased during loperamide administration (29 (2) $v 17$ (4) ppm, p $<0.05$ and $4.9(0.5)$ v $3.4(0.3) 10^{3}$ $\mathrm{ppm} / \mathrm{min}, \mathrm{p}<0.05$ ) (Fig 3 ). Interestingly, one 
TABLE II Counts (mean (SEM) of total anaerobes, methanogenic, sulphate reducing, and acetogenic bacteria in stools collected during the control, loperamide, and cisapride periods

\begin{tabular}{lccc}
\hline & Control & Loperamide & Cisapride \\
\hline Total anaerobes $^{\star}$ & $10 \cdot 9(0 \cdot 1)$ & $10 \cdot 6(0 \cdot 1)$ & $11 \cdot 0(0 \cdot 1)$ \\
Methanogenic bacteria $^{\star}$ & $6 \cdot 1(1 \cdot 5)$ & $6 \cdot 9(1 \cdot 6) \dagger \neq$ & $5 \cdot 4(1 \cdot 3) \neq \S$ \\
Sulphate reducing bacteria* $^{\star}$ & $8 \cdot 1(0 \cdot 2)$ & $7 \cdot 4(0 \cdot 3) \neq \|$ & $8 \cdot 6(0 \cdot 1) \dagger \neq$ \\
Acetogenic bacteria $^{\star}$ & $7 \cdot 2(0 \cdot 9)$ & $6 \cdot 9(0 \cdot 7)$ & $7 \cdot 4(1 \cdot 1)$ \\
\hline
\end{tabular}

* Results are expressed as $\log _{10}$ viable micro-organisms per $g$ wet weight $(n=8$, except for acetogenic bacteria for which $\mathrm{n}=2) .+\mathrm{p}<0.05 v$ control period, $\neq \mathrm{p}<0.005$ cisapride $v$

acetogenic bacteria for which $\mathrm{n}=2$ ). $\dagger \mathrm{p}<0.05 v$ control period, $\neq \mathrm{p}<0.005$
loperamide period, $\mathrm{S}=0.07 v$ control period, $\| \mathrm{p}<0.005 v$ control period.

subject (no 7) was a non-methane excretor during the control period, but became a methane excretor during loperamide administration.

Over the three periods, MTT was closely related to MCTT $(r=0.74, \mathrm{p}=0.0001, \mathrm{n}=24)$ and was inversely related to the AUC of $\mathrm{H}_{2}$ $(r=-0.62, \mathrm{p}<0.01, \mathrm{n}=24)$ (Fig 4).

\section{Mean transit time, faecal $p H$, and SCFAs}

During the control period, faecal $\mathrm{pH}$ ranged from 6.5 to $7 \cdot 2$ and was inversely related to MTT $(r=-0.87, \mathrm{p}<0.05, \mathrm{n}=8)$. Compared with the control period, faecal $\mathrm{pH}$ was significantly reduced during cisapride administration $(6.6(0.1)$ v $6.9(0.1), \mathrm{p}<0.05)$ and significantly increased with loperamide $(7 \cdot 2(0 \cdot 1) v$ $6.9(0.1), p<0.001)$. Over the three periods, MTT was inversely related to faecal $\mathrm{pH}$ $(r=-0.85, \mathrm{p}<0.001, \mathrm{n}=24)$.

During the control period, faecal SCFA concentration ranged from 51 to $90 \mathrm{mM}$, with mean molar proportions of 60,17 , and 13 for acetic, propionic, and butyric acids respectively (Table IV). MTT was inversely related
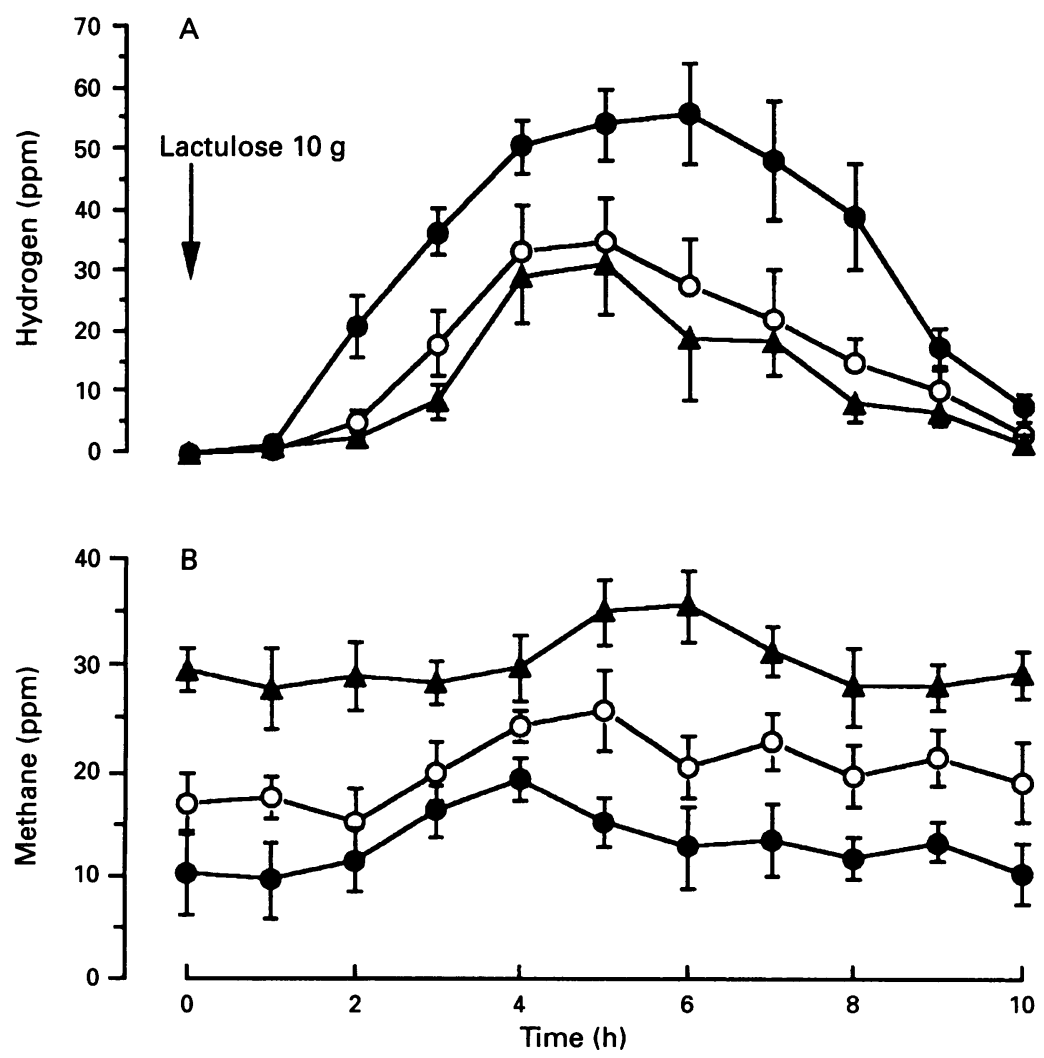

Figure 3: Breath hydrogen $(A)$ in eight healthy volunteers and methane excretions $(B)$ in four methane excretors before and after the ingestion of $10 \mathrm{~g}$ lactulose during the control (O), loperamide ( $\mathbf{\Delta}$ ), and cisapride (O) periods. Results are means (SEM).
TABLE III Breath $\mathrm{H}_{2}$ excretion (area under the curve, $10^{3}$ $\mathrm{ppm} / \mathrm{min}$ ) after ingestion of $10 \mathrm{~g}$ lactulose during the control, loperamide, and cisapride periods according to $\mathrm{CH}_{4}$ excretor status

\begin{tabular}{lccc}
\hline & Control & Loperamide & Cisapride \\
\hline $\mathrm{CH}_{4}{ }^{+}(\mathrm{n}=4)$ & $7 \cdot 2(1 \cdot 5) \dagger$ & $6 \cdot 2(0 \cdot 6) \ddagger$ & $12 \cdot 4(2 \cdot 1) \ddagger$ \\
$\mathrm{CH}_{4}(\mathrm{n}=4)$ & $11 \cdot 6(1 \cdot 6) \dagger$ & $9 \cdot 1(1 \cdot 5) \ddagger$ & $17 \cdot 8(2 \cdot 2) \ddagger$ \\
All subjects $(\mathrm{n}=8)$ & $9 \cdot 4(1 \cdot 5)$ & $7 \cdot 7(0.9) \S$ & $15 \cdot 1(2 \cdot 1)^{\star}$
\end{tabular}

Mean (SEM). $t \mathrm{p}=0.14, \neq \mathrm{p}=0.13\left(\mathrm{CH}_{4}^{-} v \mathrm{CH}_{4}^{+}\right), \mathrm{Sp}=0.30 v$ control period, ${ }^{\star} \mathrm{p}<0.05 v$ control period.

to the concentration of total SCFAs $(r=-0 \cdot 70$, $\mathrm{p}=0.05)$ and propionic and butyric acids concentrations $(r=-0.91, \mathrm{p}<0.01$ and $r=-0.70$, $\mathrm{p}=0.05$ respectively).

Compared with the control period, total SCFA concentrations, and the concentrations and percentages of propionic and butyric acid were significantly higher in the cisapride period and significantly lower in the loperamide period (Table IV). A significant opposite variation was seen in the percentage of acetic acid, whereas its concentration remained unchanged.

Over the three periods, MTT was inversely related to the concentrations of total SCFAs $(r=-0.77, \mathrm{p}<0.001)$. It was inversely related to the concentrations of propionic and butyric acids $(r=-0.94, \mathrm{p}<0.001$ and $r=-0.76$, $\mathrm{p}<0.001$ ) (Fig 5) and to the percentages of propionic and butyric acids $(r=-0.81$, $\mathrm{p}<0.001$ and $r=-0.67, \mathrm{p}<0.001)$.

\section{Discussion}

Transit changes induced by drugs in healthy volunteers given on a constant diet not only affect stool weight but also certain bacterial populations and fermentation indices. These further modifications emphasise the role of transit in some colonic events already seen during the control period and suggest that transit time could be an important factor in the individual variability of colonic fermentations. Whether these changes in faecal flora and colonic fermentation result primarily from variations in transit or are secondary to the consequences of transit variations, basally or pharmacologically induced, needs further discussion.

Inter-individual variations in the composition and activities of colonic flora ${ }^{2} 3$ as well as

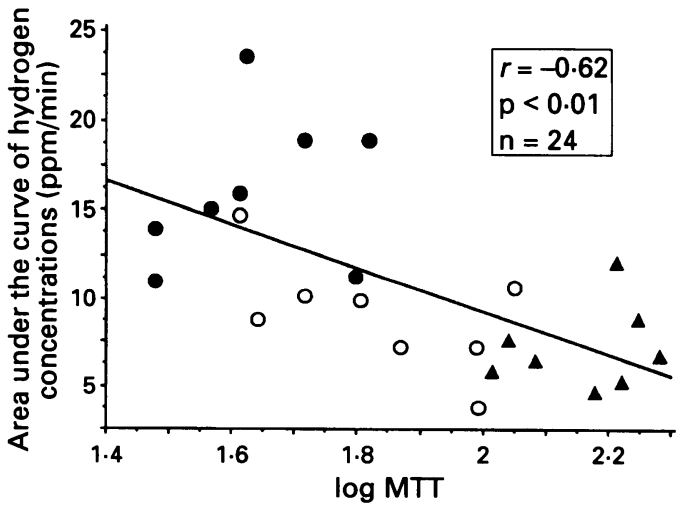

Figure 4: Correlation between mean transit time (log MTT) and breath hydrogen excretion after the ingestion of $10 \mathrm{~g}$ lactulose during the control (O), loperamide ( $\mathbf{\Delta})$, and cisapride (O) periods in eight healthy volunteers. 
TABLE IV Faecal concentrations (mean (SEM)) of short chain fatty acids (SCFAs) and molar proportions (percentages) of acetic, propionic, and butyric acids during the control, loperamide, and cisapride periods in eight healthy volunteers

\begin{tabular}{|c|c|c|c|c|c|c|}
\hline & \multicolumn{2}{|l|}{ Control } & \multicolumn{2}{|l|}{ Loperamide } & \multicolumn{2}{|l|}{ Cisapride } \\
\hline & mmoln & $(\%)$ & mmoll & $(\%)$ & $\mathrm{mmol} / \mathrm{l}$ & $(\%)$ \\
\hline $\begin{array}{l}\text { Total SCFAs } \\
\text { Acetic acid } \\
\text { Propionic acid } \\
\text { Butyric acid }\end{array}$ & $\begin{array}{l}75 \cdot 0(4 \cdot 7) \\
44 \cdot 6(2 \cdot 4) \\
13 \cdot 1(1 \cdot 1) \\
10 \cdot 2(1 \cdot 2)\end{array}$ & $\begin{array}{r}(100) \\
(60) \\
(17) \\
(13)\end{array}$ & $\begin{array}{c}61.4(4.0) \star \ddagger \\
39.5(2.7) \Uparrow \\
8.0(0.4) \dagger \lessgtr \\
6.8(0.7)^{\star}\end{array}$ & $\begin{array}{r}(100) \\
(64) \\
(13) \\
(11)\end{array}$ & $\begin{array}{l}87 \cdot 4(4 \cdot 2) \star \ddagger \\
48 \cdot 4(2 \cdot 5) \oint \\
18 \cdot 2(1 \cdot 1) \dagger \\
14.3(1 \cdot 0) \S \dagger\end{array}$ & $\begin{array}{r}(100) \\
(55) \\
(21) \\
(16)\end{array}$ \\
\hline
\end{tabular}

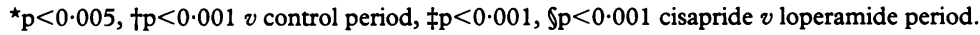

transit time ${ }^{1625-29}$ have been widely reported. On the other hand, it is generally assumed that colonic flora, 2339 faecal fermentation patterns of a given substrate, ${ }^{640}$ methane excretor status, and faecal MB concentrations ${ }^{41}{ }^{42}$ remain stable within a given subject over an extended period of time. Likewise, it is generally assumed that in controlled conditions, and despite a day to day variation, subjects with physiologically fast or slow MTT generally maintain this characteristic over a prolonged time period, ${ }^{29}{ }^{43}$ as was confirmed in our study during the control period (Fig 1). It was therefore tempting to hypothesise that the rough constancy of intra-individual transit time could be one factor responsible for the stability of certain bacterial populations and activities of colonic flora.

Although a limited number of subjects was enrolled in this study, clear individual
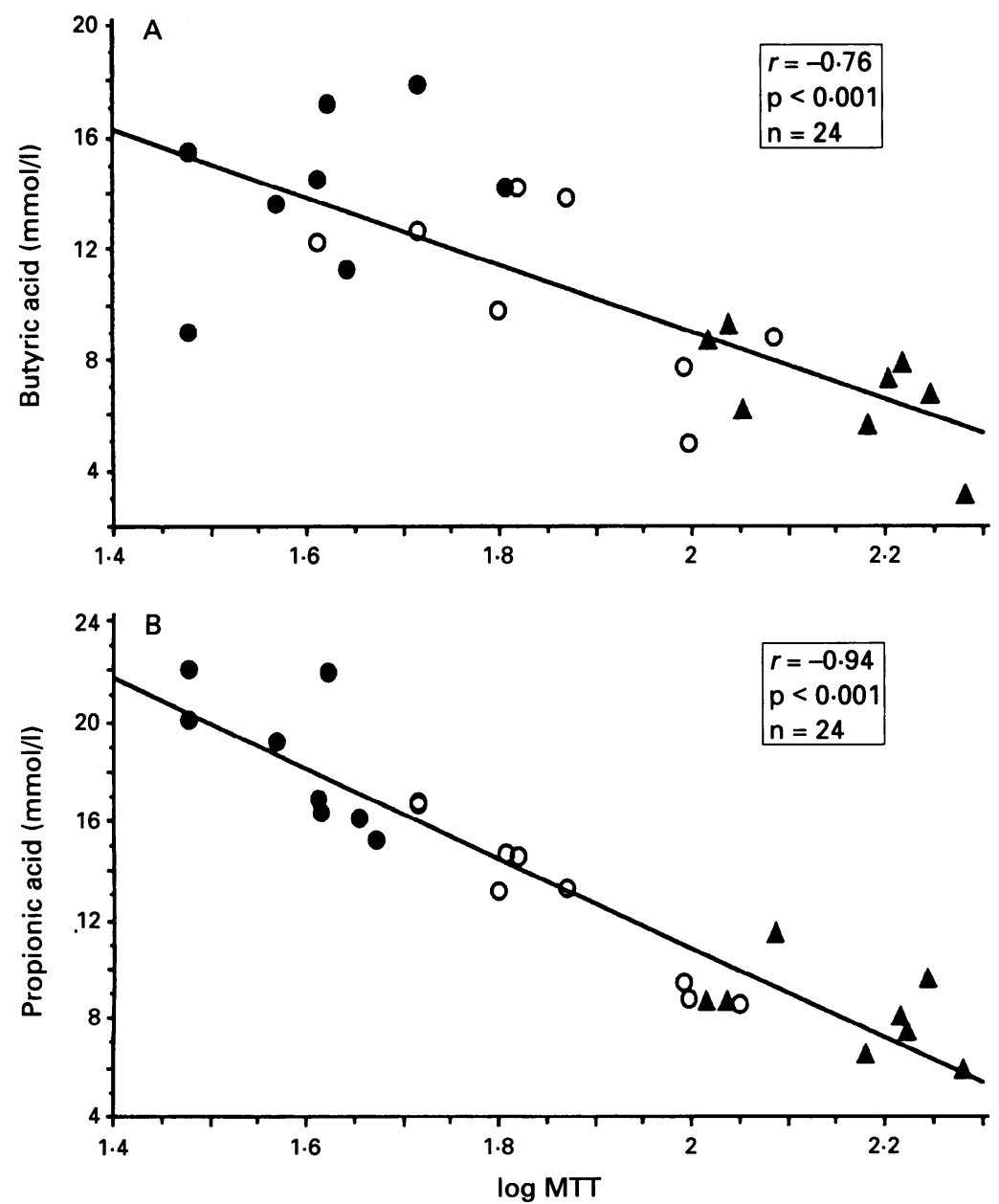

Figure 5: Correlation between mean transit time (log MTT) and concentrations of butyric $(A)$ and propionic $(B)$ acids during the control (O), loperamide ( $\mathbf{\Delta})$, and cisapride (O) periods in eight healthy volunteers. variability in transit time, faecal composition, and breath excretion of gases was observed during the control period. Indeed, subjects with spontaneously fast MTT exhaled more $\mathrm{H}_{2}$ in response to lactulose. $\mathrm{MB}$ counts and $\mathrm{pH}$ were low in their faeces, whereas SRB counts and concentrations of SCFAs and propionic and butyric acids were high in their faeces. Because it may be argued that transit is the result rather than the cause of colonic events, we used the experimental protocol designed by Stephen et al ${ }^{16}$ to demonstrate that transit influences events in the human large intestine.

Drug induced MTT changes in faecal flora did not affect the number of viable anaerobes per $g$ of faeces, but resulted in changes in $M B$ and SRB counts except for the two subjects in whom MB were below the detection level. Indeed, the increase in MTT with loperamide resulted in a significant fall in SRB counts and a significant rise in $\mathrm{MB}$. Accordingly, breath methane was higher in the fasting state and after lactulose ingestion in methane excretors (Fig 3). The reverse was roughly true with cisapride. The effect of loperamide was even strong enough to convert one non-methane excretor into a methane excretor. In this subject the MB count was basally higher than in other methane non-excretors, rising from $6 \cdot 7$ to $8 \cdot 1 \log _{10} / g$ wet weight during loperamide administration. Our findings are in agreement with the reported inverse relation between $\mathrm{MB}$ and SRB stool counts. ${ }^{1445}$ Because MB are slow growing bacteria, it is usually assumed that slow colonic transit may provide a more suitable environment for their proliferation. ${ }^{2122}$ When colonic transit time is increased and provided that $\mathrm{MB}$ are present, they may proliferate and eventually out compete SRB. Alternatively, it has been shown that sulphate availability and bile acid losses in the colon may regulate the proportion of SRB and $\mathrm{MB}$ populations. ${ }^{1046}$ During cisapride administration, MCTT was shorter, which could have reduced absorption of dietary sulphate and bile acids in the small intestine. ${ }^{1046}$

Besides modifications in $\mathrm{MB}$ and SRB counts, our data show that transit modifications change the breath excretion of gases produced in the colon. However, interpretation of these data should be cautious because breath concentrations of $\mathrm{H}_{2}$ and methane are not a reliable guide of colonic production of these gases because their rate of production significantly affects their proportion exhaled in breath. 4748

In the control period as well as in the study as a whole, MTT was inversely related to the volume of $\mathrm{H}_{2}$ excreted in breath after lactulose ingestion, and this was significantly increased during cisapride administration (Fig 3). The rise in breath $\mathrm{H}_{2}$ excretion when transit was faster cannot be explained by better diffusion from the colonic lumen towards breath gas as faster transit provides less time for colonic gas absorption and $\mathrm{H}_{2}$ is rather excreted in flatus. ${ }^{478}$ Although the rate of lactulose entry into the colon may affect breath $\mathrm{H}_{2}$ excretion, ${ }^{49}$ the rise in $\mathrm{H}_{2}$ when transit was faster 
was more probably as a result of reduced consumption of $\mathrm{H}_{2}$ produced in the colon, which could have resulted from increased colonic mixing or a decrease in some $\mathrm{H}_{2}$ consuming organisms, or both. ${ }^{20}$ Strocchi and Levitt ${ }^{20}$ have suggested on the basis of in vitro studies that the amount of $\mathrm{H}_{2}$ released from well stirred faecal contents is many times greater than from poorly stirred faeces. It could thus be speculated that basal variations in colonic mixing or those induced by cisapride account for the relation between fast transit and the rise in $\mathrm{H}_{2}$ excretion. Alternatively, changes in $\mathrm{H}_{2}$ consuming flora may have reduced intracolonic $\mathrm{H}_{2}$ consumption. Acetogenic bacteria may grow at low $\mathrm{pH}$ values (optimum $\mathrm{pH}=6$ ) and, as SRB, are competitively displaced by $\mathrm{MB}$ in human faeces. ${ }^{50} 51$ In this study, we assessed acetogenic bacteria only in the last two subjects and found no change in their counts during the three periods. During cisapride administration, SRB stool counts increased, whereas $\mathrm{MB}$ counts tended to decrease. $\mathrm{H}_{2}$ excretion increased, while breath methane was lower in the fasting state and after lactulose ingestion in methane excretors. Thus, although SRB were increased during cisapride administration, they did not consume $\mathrm{H}_{2}$ efficiently and, interestingly, breath $\mathrm{H}_{2}$ after lactulose ingestion rose in methane excretors but also in non-methane excretors (Table III). These findings seem to support previous reports showing that in human faeces MB outcompete other $\mathrm{H}_{2}$ consuming bacteria for $\mathrm{H}_{2} \cdot{ }^{20} 45$

However, it should be noted that methane excretion in breath and $\mathrm{MB}$ were at a higher level during loperamide administration, while the volume of exhaled $\mathrm{H}_{2}$ was hardly reduced. One possible explanation for this is that the site of lactulose fermentation is physically separated from that of methane formation, especially in situations where the colonic transit time is slow. This concept is supported by studies in methane excretors showing that methane production occurs mainly in the left colon, 4152 whereas the right colon should be the primary site of lactulose fermentation.

Our results confirm that MTT is related to faecal weight, water output, and $\mathrm{pH} . .^{1621}$ Moreover, in the control period as well as in the study as a whole, MTT was inversely related to the faecal concentration of total SCFAs and propionic and butyric acids. Speeding up transit pharmacologically produced lower faecal $\mathrm{pH}$, while concentrations of SCFAs and propionic and butyric acids rose by 17,39 , and $40 \%$, respectively. The reverse was true when transit was slowed down by loperamide. Transit variations could have induced changes in the faecal amounts and proportions of SCFAs because of changes in substrates flowing to the colon or changes in the environmental conditions of the large intestine (such as $\mathrm{pH}$, or both). Fast MTT was associated with fast MCTT in both control and cisapride periods, which may have increased the delivery of fermentable substrates to the colon, in particular digestible starch $^{1213}$ leading to higher production of propionate or butyric, or both. ${ }^{6} 5354$ Increased substrate supply to the colon may in turn lower intraluminal $\mathrm{pH}$, a factor that by itself can change fermentation end products. ${ }^{55}$ In addition, changes in transit time may directly affect the amount and pattern of fermentation end products. ${ }^{18} 195657$ Fast transit through the colon could reduce SCFA absorption, and changes in their faecal excretion pattern might be due to differences in SCFA absorption from the colonic lumen. ${ }^{58}$ Lastly, as mentioned above fast transit was associated with reduced $\mathrm{H}_{2}$ removal, which could exert selective pressure on the colonic bacteria changing the balance between species or between metabolic pathways. ${ }^{59}$

In conclusion, this study shows that differences in MTT between healthy volunteers given a constant diet are associated with differences in $\mathrm{H}_{2}$ consuming flora and certain indices of colonic fermentation, which may also be induced by changing transit time by pharmacological means. Factors (constitutional or environmental) affecting transit thus might play an important part in determining inter-individual differences in the composition and certain activities of colonic flora. Regarding the potential effects of some of these fermentation products (for example, butyrate) on the colonic mucosa, ${ }^{1}$ it is therefore reasonable to assume that these changes may have some important implications in the pathophysiology of certain colorectal diseases.

We thank $C$ Bonnet for his excellent technical assistance. This research was supported in part by Eridania Béghin-Say and by a grant from the French Ministry for Research (Aliment Demain contract No: 92 G 0554).

1 Macfarlane GT, Cummings JH. The colonic fermentation and large bowel digestive function. In: Phillips $\mathrm{SF}$, Pemberton JH, Shorter RG, eds. The large intestine: physiology, pathophysiology and diseases. New York: physiology, pathophysiology

2 Gorbach SL, Nahas L, Lerner PI, Weinstein L. Studies of intestinal microflora. Effects of diet, age, and periodic sampling on numbers of faecal microorganisms in man. Gastroenterology 1967; 53: 845-55.

3 Simon GL, Gorbach SL. Intestinal flora in health and disease. Gastroenterology 1984; 86: 174-93.

4 Hoverstad T, Fausa O, Bjorneklett A, Bohmer T. Short chain fatty acids in normal human feces. Scand $\mathcal{f}$ Gastroenterol 1984; 19: 375-81.

5 Rasmussen HS, Holtug K, Andersen JR, Krag E, Mortensen PB. The influence of ispaghula husk and lactulose on the in vivo and the in vitro production lactulose on the in vivo and the in vitro production
capacity of short chain fatty acids in humans. Scand $\mathcal{f}$ capacity of short chain fatty acids
Gastroenterol 1987; 22: 406-10.

6 Weaver GA, Krause JA, Miller TL, Wolin MJ. Constancy of glucose and starch fermentations by two different human faecal microbial communities. Gut 1989; 30: 19-25.

7 McBurney MI, Thompson LU. Effect of human faecal donor on in vitro fermentation variables. Scand $f$ Gastroenterol 1989; 24: 359-67.

8 Bond JH, Levitt MD. Use of pulmonary hydrogen $\left(\mathrm{H}_{2}\right)$ measurements to quantitate carbohydrate malabsorption: study of partially gastrectomized patients. $\mathcal{f}$ Clin Invest 1972; 51: $1219-25$.

9 Hill MJ. Diet and the human intestinal bacterial flora. Cancer Res 1981; 41: 3778-80.

10 Florin TH, Jabbar IA. A possible role for bile acid in the control of methanogenesis and the accumulation of hydrogen gas in the human colon. $\mathcal{F}$ Gastroenterol Hepatol 1994; 9: 112-7.

11 Wrong OM, Edmonds CJ, Chadwick VS. The large intestine: its role in mammalian nutrition and homeostasis. Lancaster: MTP Press, 1981

12 Chapman RW, Sillery JK, Graham MM, Saunders DR. Absorption of starch by healthy ileostomates: effect of transit time and of carbohydrate load. Am $\mathcal{f}$ Clin Nutr 1985; 41: 1244-8.

13 Holgate AM, Read NW. Relationship between small bowel transit time and absorption of a solid meal. Dig Dis $S c i$ 1983; 28: 812-9.

14 Southgate DAT, Durnin JVGA. Calorie conversion factors. An experimental reassessment of the factors used in the calculation of the energy value of human diet. Br $\mathcal{f}$ Nutr 1970; 24: 517-35. 
15 Stephen AM, Cummings JH. The microbial contribution to human faecal mass. $\mathcal{F}$ Med Microbiol 1980; 13: 45-56.

16 Stephen AM, Wiggins HS, Cummings JH. Effect of changing transit time on colonic microbial metabolism in man Gut 1987; 28: 601-9.

17 Isaacson HR, Hinds FC, Bryant MP, Owens FN. Efficiency of energy utilisation by mixed rumen bacteria in continuous culture. F Dairy Sci 1975; 58: 1645-59.

18 Silley P, Armstrong DG. Changes in metabolism of the rumen Bacterium Streptococcus Bovis H13/1 resulting from alteration in dilution rate and glucose supply per unit time. $\mathcal{F}$ Appl Bacteriol 1984; 57: 345-53.

19 Kotarski SF, Salyers AA. Effect of long generation times on growth of Bacteroides thetaiotaomicron in carbohydratelimited continuous culture. 7 Bacteriol 1981; 146: 853-60.

20 Strocchi A, Levitt MD. Factors affecting hydrogen production and consumption by human faecal flora. $\mathcal{F}$ Clin Invest 1992; 89: 1304-11.

21 Stephen AM, Wiggins HS, Englyst HN, Cole TJ, Wayman BJ, Cummings JH. The effect of age, sex and level of intake of dietary fibre from wheat on large bowel functio in thirty healthy subjects. Br F Nutr 1986; 56: 349-61.

22 Mah RA, Ward DM, Baresi L, Glass TL. Biogenesis of methane. Ann Rev Microbiol 1977; 31: 309-14.

23 Mckay LF, Eastwood MA, Brydon WG. Methane excretion in man - a study of breath, flatus, and faeces. Gut 1985; 26: 69-74.

24 Melcher EA, Levitt MD, Slavin JL. Methane production and bowel function parameters in healthy subjects on low and high-fibre diets. Nutr Cancer 1991; 16: 85-92.

25 McIntyre AS, Thompson DG, Day S, Burnham WR, Walker ER. Modulation of human upper intestinal nutrient transit by a beta adrenoreceptor mediated pathway. Gut 1992; 33: 1062-70.

26 Cloarec D, Bruley des Varannes S, Bizais Y, Lehur PA, Galmiche JP. Reproductibilité du temps de transit orocaecal et de la production d'hydrogène mesurés par les tests respiratoires. Gastroenterol Clin Biol 1992; 16: 388-94.

27 Bond JH, Levitt MD, Prentiss R. Investigation of small bowel transit time in man utilizing pulmonary hydrogen $\left(\mathrm{H}_{2}\right)$ measurement. $\mathcal{F}$ Lab Clin Med 1975; 85: 546-55.

28 Read NW, Miles CA, Fisher D, Holgate AM, Kime ND, Mitchell MA, et al. Transit of the meal through the stomach, small intestine and colon in normal subjects and its role in the pathogenesis of diarrhea. Gastroenterology its role in the path

29 Cummings $\mathrm{JH}$. Diet and transit through the gut. $\mathcal{F}$ Plant Foods 1978; 3: 83-95.

30 Colombel JF, Flourié B, Neut C, Florent Ch, Leblond A, Rambaud JC. La méthanogenèse chez l'homme. Gastroenterol Clin Biol 1987; 11: 694-700.

31 Cummings JH, Jenkins DJA, Wiggins HS. Measurement of the mean transit time of dietary residue through the gut. Gut 1976; 17: 210-9.

32 Raibaud P, Dickinson AB, Sacquet E, Charlier H, Mocquot G. La microflore du tube digestif du rat. I. Techniques d'étude et milieux de culture proposés. Ann Inst Pasteur 1966; 110: 568-90.

33 Pfenning N, Widdel F, Truper HG. The prokaryotes. $A$ handbook on the habitat, isolation and identification of bachandbook on the habitat, isolation and

34 Widdel F. Biology of anaerobic microorganisms. New York: John Wiley, 1988.

35 Balch WE, Fox GE, Magrum CJ, Woese CR, Wolfe RS. Methanogens: reevaluation of a unique biological group. Microbiol Rev 1979; 43: 260-96.

36 Pochart P, Lemann F, Flourie B, Pellier P, Goderel I, Rambaud JC. Pyxigraphic sampling to enumerate methanogens and anaerobes in the right colon of healthy humans. Gastroenterology 1993; 105: 1281-5.

37 Greening RC, Leedle JAZ. Enrichment and isolation of Acetitomaculum ruminis, gen, nov, sp, nov: acetogenic 399-406.
38 Jouany JP. Dosage des acides gras volatils (AGV) et des alcools dans les contenus digestifs, les jus d'ensilage, les cultures bactériennes et les contenus de fermenteurs anaérobies. Sciences de Aliments 1982; 2: 131-44.

39 Bornside GH. Stability of human faecal flora. Am f Clin Nutr 1978; 31: 141-4.

40 Mc Burney MI, Thompson LU. Effects of human faecal inoculum on in vitro fermentation variables. $B r \mathcal{F}$ Nutr 1987; 58: 233-43.

41 Bond JH, Engel RR, Levitt MD. Factors influencing pulmonary methane excretion in man. $\mathcal{f}$ Exp Med 1971; 133: 572-88.

42 Miller TL, Wolin MJ. Stability of Methanobrevibacter smithii populations in the microbial flora excreted from the human large bowel. Appl Environ Microbiol 1983; 45: 317-8.

43 Cummings JH. Constipation. In: Misiewicz JJ, Pounder RE, Venables CW, eds. Diseases of the gut and pancreas. 2nd ed. Oxford: Blackwell Scientific, 1994: 51-69.

44 Pochart P, Dore J, Lemann F, Goderel I, Rambaud JC. Interrelations between populations of methanogenic archaea and sulfate reducing bacteria in the human colon. FEMS Microbiol Lett 1992; 98: 225-8.

45 Strocchi A, Furne JK, Ellis CJ, Levitt MD. Competition for hydrogen by human faecal bacteria: evidence for the predominance of methane producing bacteria. Gut 1991; 32: 1498-501.

46 Christl SU, Gibson GR, Cummings JH. Role of dietary sulphate in the regulation of methanogenesis in the human large intestine. Gut 1992; 33: 1234-8.

47 Hammer HF. Colonic hydrogen absorption: quantification of its effect on hydrogen accumulation caused by bacterial fermentation of carbohydrates. Gut 1993; 34: 818-22.

48 Christl SU, Murgatroyd PR, Gibson GR, Cummings JH. Production, metabolism, and excretion of hydrogen in the large intestine. Gastroenterology 1992; 102: 1269-77.

49 Read NW, Al Ganabi MN, Bates TE, Holgate AM, Cann PA, Kinsman RI, et al. Interpretation of the breath $\mathrm{H}_{2}$ profile obtained after ingestion of a solid meal containing unavailable carbohydrates. Gut 1985; 26: 834-42.

50 Lajoie SF, Bank S, Miller TL, Wolin MJ. Acetate production from hydrogen and $\left({ }^{13} \mathrm{C}\right)$ carbon dioxide by the microflora of human feces. Appl Environ Microbiol 1988; 54: 2723-7.

51 Gibson GR, Cummings JH, Macfarlane GT, Allison C, Segal I, Vorster $\mathrm{HH}$, et al. Alternative pathways for hydrogegal I, Vorster HH, et al. Alternative pathways for hydrogen disposal during

52 Flourie B, Pellier P, Florent C, Marteau P, Pochart P, Rambaud JC. Site and substrates for methane production in human colon. Am $\mathcal{f}$ Physiol 1991; 260: G752-7.

53 Macfarlane GT, Englyst HN. Starch utilisation by the human large intestinal microflora. $\mathcal{f}$ Appl Bacteriol 1986; 60: 195-201.

54 Scheppach W, Fabian C, Sachs M, Kasper H. The effect of starch malabsorption on faecal short chain fatty acid excretion in man. Scand $\mathcal{f}$ Gastroenterol 1988; 23: 755-9.

55 Finlayson $\mathrm{HJ}$. The effect of $\mathrm{pH}$ on the growth and metabolism of Streptococcus bovis in continuous culture. $\mathcal{F} \mathrm{Appl}$ Bacteriol 1986; 61: 201-8.

56 Goodlad JS, Mathers JC. Large bowel fermentation in rats given diets containing raw peas (Pisum sativum). $\mathrm{Br} \mathcal{F}$ Nutr 1990; 64: 569-87.

57 Mathers JC, Dawson LD. Large bowel fermentation in rats eating processed potatoes. Br f Nutr 1991; 66: 313-29.

$58 \mathrm{McNeil}$ NI, Cummings JH, James WPT. Short chain fatty acid absorption by the human large intestine.Gut 1978; 19: 819-22.

59 Thauer $R$. Limitation of microbial $\mathrm{H}_{2}$ formation via fermentation. In: Schlegel HG, Bornea J, eds. Microbial energy conversion. Gottingen: Eric Golt KG, 1976: $201-4$. 